\title{
The Impact of Human Resource Management Practices in Financial Organizations on Job Satisfaction
}

\author{
Evgeniy Valishin ${ }^{1 *}$ \\ ${ }^{1}$ Financial University under the Government of the Russian Federation, Moscow, Russia \\ *Email: ewgeni-57@ mail.ru
}

\begin{abstract}
Job satisfaction is considered an essential factor in developing a professional's personality, closely related to work motivation. Job satisfaction is a necessary component of human resources, an indicator of both the current and prospective position of the organization. In modern conditions of functioning of organizations, employee satisfaction is associated with specific positive consequences: high labour motivation, increased labour efficiency, staff involvement (loyalty to the organization).

Study purpose. To investigate the differences in the degree of satisfaction with various aspects of employees' work in financial sector organizations in the digital economy.

For this purpose, in practice, a descriptive-analytical approach was used to identify the degree of employee job satisfaction in the organization. Statistical analysis of the study results was carried out to identify the relationship between the variables (Z-test, correlation analysis). The study solved the problem of determining significant factors in managing an organization's human resources that affect job satisfaction (remuneration, job security, level of responsibility at work, recognition, leadership style, career opportunities, training and development in a professional environment).

Results. A positive relationship has been revealed between the practice of human resource management in financial sector organizations and employee satisfaction. The study recommends improving management in the personnel utilisation subsystem by optimising the financial compensation system and workplace design, positively affecting employee satisfaction.
\end{abstract}

Keywords: Human resource management, Financial sector, Motivation, Job satisfaction, HR management practices.

\section{INTRODUCTION}

Today, more and more attention is being paid to the issue of human resource management in the digital economy. There is a need to determine the efficiency level of managing such resources and its impact on employee satisfaction with work results. It is necessary to consider the problematic aspects in management that affect employee satisfaction and identify measures to increase employee satisfaction and increase motivation. The high importance of labour motivation can be deduced from the economic goals of the organization. And job satisfaction can be interpreted as one of the aspects of humane goals that many organizations also value highly.

Most authors see job satisfaction as a time-stable and relatively stable assessment of the actual situation in the organization. Thus, the concept of job satisfaction converges with the attitude to work (or to the work situation).

Job satisfaction is one of the most researched topics in organizational behaviour and human resource management $[1,2,3]$. Work and satisfaction with it is a complex relationship because it involves the employee's reaction to various aspects of work or its parameters, such as work, salary, working conditions, relationships with 
managers and colleagues, etc. [4-6]. Studies [7, 8] have confirmed the presence of varying degrees of satisfaction with professional activities among employees of financial organizations.

The survey conducted in the study [9] showed the presence of significant factors affecting the reduction of the degree of dissatisfaction with the work of employees of financial organizations.

In work [10], attention is focused on the connection of dissatisfaction with the professional activity performed with the peculiarities of the tasks being solved, leadership style (management), material remuneration, career management, organizational conditions and behaviour, socio-psychological climate. In addition, the socialisation and motivation of employees in the organization are related to their performance and job satisfaction.

\section{RESEARCH METHODOLOGY}

Based on the structure of the organization's human resource management system its subsystems (provision, implementation and development), the following assumptions were considered: employees are "satisfied" with wages and other rewards, and motivation, leadership style (working time management), as well as guaranteed employment and the level of responsibility and autonomy in work; employees are "satisfied" with the process of socialisation in the organization (career management, training and development). The results of a survey of employees of financial sector organizations were analysed. The survey was conducted remotely using GoogleDocs. The answers to the questions used in the questionnaire were then subjected to statistical analysis. Employees answered seven types of questions regarding employment, remuneration, career management, training and development, management style, responsibility and autonomy at work, encouragement and recognition. In addition, information posted in the public domain on the website of the Bank of Russia in the section "Information on credit institutions" was used. The choice of sources for obtaining information (the questionnaire method with the application of a 5-point Likert rating scale: very dissatisfied to very satisfied) is predetermined by the specifics of the work of financial organizations (a high degree of work intensity). The target group is employees of financial sector organizations. 92 questionnaires were analysed. Tools. Statistical analysis of the data obtained (Z-test, correlation analysis) was used to conclude the relationship between variables. The statistical significance of the study results was determined using the Pearson correlation coefficient.

\section{RESULTS AND DISCUSSION}

The data indicate that middle-aged workers (29-39 years old) with higher education and more than 10 years of work experience predominate in financial organizations. The answers to the questionnaire questions were processed, and a value and standard deviation were determined for each question.

The highest employee satisfaction is associated with career growth, $52 \%$, and job security, $53 \%$. At the same time, these are the only measurements that exceed $50 \%$ of the satisfaction level. 46.2\%, - training and development; $39.1 \%$ - responsibility for work and the bonus system (recognition); working time management (management style) - 36.5\%; $27.3 \%$ of employees are satisfied with the remuneration received. Next, let's look at the employees' responses to each factor.

Factors in the personnel utilisation subsystem:

1. Job security (average; standard deviation; standard error; Z-score calculation; probability): 3,04; 1,25; 0,13; $-0,04 ; \mathrm{P}(\mathrm{X}<3)=\mathrm{P}(\mathrm{Z}<(-0,04))=0,48$

$53 \%$ of respondents noted high satisfaction with the employment guarantee. In addition, $47 \%$ of all employees who participated in the study rated this factor below 3 points. Thus, employees of the financial sector are satisfied with guaranteed work.

2. Salary (average; standard deviation; standard error; Z-score calculation; probability): 2,40; 1,04; 0,11; 0,56; $\mathrm{P}(\mathrm{X}<3)=\mathrm{P}(\mathrm{Z}<0,56)=0,71$

$27.3 \%$ of employees reported a high level of satisfaction, i.e. employees are satisfied with wages and other financial incentives in the financial sector. $72.7 \%$ of the employees participating in the study are not completely satisfied with their earnings and estimate it below 3 points.

3. Responsibility at work (average; standard deviation; standard error; Z-score calculation; probability): 2,60; 1,408; 0,146; 0,27; $\mathrm{P}(\mathrm{X}<3)=\mathrm{P}(\mathrm{Z}$ $<0,27)=0,61$

$60.9 \%$ of employees are not satisfied with the degree of responsibility at work and assesses it below 3 points. $39.1 \%$ of employees noted a higher level of satisfaction. Employees are satisfied with teamwork and the duties assigned to them.

4. Working time management (management style): (average; standard deviation; standard error; Z-score calculation; probability): 2,54; 1,411;0,146; 0,32; P (X $<3)=\mathrm{P}(\mathrm{Z}<0,32)=0,63$

$63.5 \%$ of employees are not satisfied with the management styles applied in practice and rated it below 3. $36.5 \%$ of employees expressed satisfaction with the management style.

5. Awards and recognition (average; standard deviation; standard error; Z-score calculation; probability): 2,70; 1,061; 0,110; 0,28; $\mathrm{P}(\mathrm{X}<3)=\mathrm{P}(\mathrm{Z}$ $<0,27)=0,61$ 
$60.9 \%$ of employees are not satisfied with this aspect of motivation and rated it below 3. $39.1 \%$ of employees are "satisfied" with the bonus system in the financial sector.

Factors of the personnel development and training subsystem that affect employee satisfaction:

1. Career growth (average; standard deviation; standard error; Z-score calculation; probability): 3,08; 1,$361 ; 0,141 ;-0,06 ; \mathrm{P}(\mathrm{X}<3)=\mathrm{P}(\mathrm{Z}<(-0,06))=0,47$

$48 \%$ of employees are not satisfied with this aspect of motivation and rated it below 3. 52\% are "satisfied" with promotion and career growth in the financial sector.

2. Professional training and development (average; standard deviation; standard error; Z-score calculation; probability): 2,83; 1,348; 0,140; 0,$11 ; \mathrm{P}(\mathrm{X}<3)=\mathrm{P}(\mathrm{Z}$ $<0,11)=0,55$

$53.8 \%$ of employees are not satisfied with this motivation factor and rated it below 3. 46.2\% of employees expressed satisfaction with professional training and development in the financial sector.

To analyse the satisfaction of employees of financial sector organizations, seven significant factors in human resource management were considered. The analysis of the answers to the questionnaire showed that employees have different degrees of satisfaction with their professional activities. In career management and job security, employees showed a relatively high level of satisfaction. Employees showed a significantly lower degree of satisfaction in other satisfaction factors, such as salary, working time management (management style), autonomy and responsibility, recognition of work results, training and development.

The statistical analysis results revealed that employees are not satisfied enough with the motivation tools used in financial organizations. The best evaluation indicators are promotion and job security, while employees are least satisfied with their financial situation (remuneration). As a result of comparing their expectations and the actual situation, employees give a positive or negative assessment of one or another aspect of the work. In the case of a positive assessment, there is job satisfaction, which can be both progressive and stabilised.

In the case of a negative assessment, there may be pessimistic satisfaction, false satisfaction, fixed and constructive dissatisfaction with work. Specifying by type of employee satisfaction will require additional research.

Thus, a positive relationship has been revealed between the practice of human resource management in financial sector organizations and employee satisfaction. Improving management in the personnel utilisation subsystem can be recommended by optimising the financial compensation system and workplace design, positively affecting employee satisfaction level. In the personnel development and training subsystem, special attention should be paid to optimising the practice of managing the career of employees, which is vital in this management subsystem.

\section{CONCLUSION}

The study results show that financial sector organizations should analyse and change motivational management in the digital economy. Optimisation of subsystems for the use of personnel and development and training should begin with a system of employee compensation, changes in management style, and job responsibilities. It should be emphasised that financial remuneration serves to meet many needs, has a symbolic character of the value of the work performed. And most importantly, it serves as a status symbol, expresses recognition, gives confidence to the employee and a certain degree of freedom in life.

Professional activity is significant for many employees and is a source of meaning and individual value in society. Most workers are looking for responsibility, self-determination, control and autonomy in the workplace that will allow them to apply and develop their talents and abilities. Employees often appreciate the opportunity to acquire new skills and prefer diverse, creative and often complex tasks to simple, routine work.

It should be emphasised that the study of the relationship between job satisfaction and work behaviour, again and again, indicates a significant influence of mediating variables. Professions for which activity is inherent, where significant factors are highly expressed, lead to greater satisfaction than professions for which work is characterised mainly by hygienic factors. Specifying the types of employee satisfaction will require additional research, and correlating them with the nature of the requirements imposed on them in the organization will require further research.

\section{REFERENCES}

[1] M. Fila, L. Paik, R. Griffeth, D. Allen, Disaggregating Job Satisfaction: Effects of Perceived Demands, Control, and Support // Journal of Business and Psychology 29(4) (2014) 639-649.

[2] T. Haesevoets, R.C. Folmer, D. De Cremer, A. Van Hiel, Money Isn't All That Matters: The Use of Financial Compensation and Apologies to Preserve Relationships in the Aftermath of Distributive Harm // Journal of Economic Psychology 35 (2013) 95107154

[3] H.G. Heneman, T.A. Judge, Compensation attitudes: a review and recommendations for future 
research, In S.L. Rynes, B. Gerhart (Eds.). Compensation in Organizations: Progress and Prospects, San Francisco: Jossey-Bass, 2000, pp. 61-103.

[4] Z. Filiz, An Analysis of the Levels of Job Satisfaction and Life Satisfaction of the Academic Staff // Social Indicators Research 116(3) (2014) 793-808.

[5] A.J. Kinicki, C.A. Schriesheim, F.M. McKee-Ryan, K.P. Carson, Assessing construct validity of the job descriptive index: Review and meta-analysis // Journal of Applied Psychology 87(1) (2002) 14-32.

[6] J.M. Millan, J. Hessels, R. Thurik, R. Aguado, Determinants of job satisfaction: a European comparison of self-employed and paid employees // Small Business Economics 40(3) (2013) 651-670.

[7] A.A. Bailey, F. Albassami, \& S. Al-Meshal, The roles of employee job satisfaction and organizational commitment in the internal marketing-employee bank identification relationship. International Journal of Bank Marketing 34(6) (2016) 821-840. DOI: https://doi.org/10.1108/IJBM-06-2015-0097

[8] E. George, Job-related stress and job satisfaction: a comparative study among bank employees, Journal of Management Development 34(3) (2015) 316329.

[9] B. Chowdhary, Job satisfaction among bank employees: An analysis of the contributing variables towards job satisfaction. International journal of scientific \& technology research 2(8) (2013) 11-20. Retrieved from: http://www.ijstr.org/finalprint/aug2013/Job-Satisfaction-Among-BankEmployees-An-Analysis-Of-The-ContributingVariables-Towards-Job-Satisfaction.pdf

[10] S. Panghal \& S. Bhambu, Factors influencing job satisfaction of banking sector employees in India, International Journal of New Innovations in Engineering and Technology 1(3) (2013) 41-44. 